\title{
An Aboriginal fish trap on the Swan Coastal Plain: the Barragup mungah
}

\author{
Martin Gibbs \\ Department of Archaeology, School of Philosophical and Historical Inquiry, \\ University of Sydney, New South Wales 2006, Australia. Email: Martin.Gibbs@sydney.edu.au
}

\begin{abstract}
At the time of European invasion the Aboriginal people of the Swan Coastal Plain were engaged in a complex series of social economic and ceremonial networks which required regular faceto-face gatherings. The annual winter meeting at Barragup on the Serpentine River appears to have been one of the most important of these events, sustained by the operation of a wooden mungah fishtrap which allowed harvesting of sea mullet (Mugil cephalus) and Australian salmon (Arripis truttaceus). This paper provides historical material on the nature and operation of the Barragup mungah and the associated gathering as part of an appreciation of the research of the ethnohistorical research by Sylvia Hallam.
\end{abstract}

KEYWORDS: South-West of Western Australia, fishing, weirs, gatherings

\section{INTRODUCTION}

Sylvia Hallam's contributions to Western Australian archaeological research and education have been manifold, although it is likely that her most enduring intellectual contributions will be her long-term ethnohistorical projects. In a series of papers through the 1970s and 1980s, Hallam developed a dialogue regarding the nature of pre-contact and early historic period Aboriginal social, economic and ceremonial systems in the South-West Western Australia, largely informed by her British historical geographical and landscape archaeological approaches. This work coincided with and contributed to the emerging debate surrounding the apparent intensification of Aboriginal society and economy in the mid-late Holocene (Lourandos 1980, 1983). Ethnohistorical materials played a significant role in this reinterpretation by providing data on or analogies for the processes creating the later part of the archaeological record, or conversely acting as the starting point for direct historical approaches regarding the evolution of Late Holocene systems (cf. McBryde 1979, 1984, 1986).

By the mid 1908s, Hallam's ethnohistorical research had embraced various topics, including Aboriginal firing (Hallam 1975, 1985), social interactions (Hallam 1977, 1983) and yam cultivation in the South-West (Hallam 1986). When the author approached her about possible projects examining the nature and significance of ceremonial and trade networks on the Swan Coastal Plain, her immediate reaction was that the annual gathering at the Barragup fish weir on the Serpentine River might provide a good focus. In retrospect this was almost certainly something of interest to Sylvia herself and quite probably a potential direction for her own research, so passing on the project was an act of great generosity. This paper presents some of the substance of the resulting Honours dissertation (Gibbs 1987), completed under Sylvia's supervision but never published.

\section{ABORIGINAL LIFE AND ECONOMY ONTHE SWAN COASTAL PLAIN}

The Swan Coastal Plain encompasses the relatively flat, sandy area approximately 20-30 $\mathrm{km}$ wide lying west of the Darling Scarp, running several hundred kilometres from approximately the Hill River (Jurien), southwards to modern Dunsborough (Churchward and McArthur 1980). Originally covered with light woodlands and coastal heath, the plain is dissected by a series of major rivers flowing westward down from the ranges, as well as a chain of fresh water swamps and wetlands running roughly north to south. The climate is Mediterranean, characterized by dry summers and wet winters.

The nature of Aboriginal society and economy on the Swan Coastal Plain in the contact period has been summarised by various writers (Meagher 1974; Meagher and Ride 1979; Green 1984) and need not be detailed here. However, it is clear that the Swan Coastal Plain was well watered and rich in resources year round, the family groups who formed the usual 
residential unit moving only moderate distances to take best advantage of seasonal resources. These smaller groups would on occasion make longer journeys and coalesce into larger masses for participation in various social, economic and ceremonial activities, described further below.

There was a relatively high permanent population on the Swan Coastal Plain, especially in the areas around the Swan and Murray Rivers. There were probably five or so major communities spread from north to south and focussed along the main riverestuarine systems. Although it is difficult to be sure of the original names of groups, Pinjarup seems to have covered the collective community of the Murray-Peel region, with an early report suggesting this was composed of three smaller groups, the Yundungup, Kulinup and Kumbernup, totalling about 100 people (Richards 1978: 18).

The eastern boundaries of the coastal plain groups included some territory within the Darling Ranges (Armstrong 1836), although there was probably limited intensive usage beyond the first few foothills and some of the valleys within (Moore 1835, 1836; Hammond 1933; Pearce 1982). There is considerable evidence to suggest that although the Swan Coastal Plain communities shared the same language and material culture of the greater South-West (Nyungar or Bibbulmun) cultural bloc, the Ranges formed a boundary that created them as a distinct sub-group.

The Darling Range ... formed the east boundary of the Beeda-kala, Wadarndee or coastal Bibbulmun. The beelagur (river people) followed the rivers up on the other side for some distance inland beyond the Darling Range, and so brought the Bibbulmun relations further inland into the neighbourhood of the Meening people (their nearest eastern neighbours). They intermarried with the Bibbulmun and vice-versa, and hence Bibbulmun may visit their neighbours 'over the hills' because of these marriages, but the hill people were still boyun-gur [stone or hill people]. (Bates n.d. II, 1, 12)

This division and naming of groups on the basis of dominant landform features is consistent with Tindale's notions of ecological transitions forming boundaries for Aboriginal cultural groups (Tindale 1974, 1976). It is also borne out by an analysis of interaction patterns between communities, which clearly shows frequent and intensive relations between the groups along the coastal plain, contrasting to much more occasional contacts with neighbouring groups within and east of the Darling Ranges (Gibbs 1987).

The yearly cycle encompassed a range of intra- and inter-community gatherings at which a combination of social (e.g. betrothals, formalised fighting, sporting, friend making), economic (e.g. trading, gift giving) and ceremonial (including initiation) activities took place. These gatherings were usually based around a super-abundance of at least one animal or vegetable resource, capable of supporting a population of up to several hundred people for anywhere from a fortnight to a month or more, and sometimes requiring different forms of intensive extraction (e.g. Perth Gazette 15/2/1834; Perth Gazette 2/5/1835; Bunbury 1930). Collection and distribution of the 'communion' resource was usually controlled by the host group and subject to various strictures based on relationships between groups and individuals, age or sexual divisions, participation in ceremony, or totemic relationships to specific plants or animals (e.g. Bates 1985: 152, 243; Austin in Roth 1902: 57).

Although various communal meetings and intensive resource extraction techniques are described in the historical record of the Swan Coastal Plain, the most outstanding in terms of the depth of information available is the semi-regular and possibly annual activity surrounding the Barragup fish weir, situated on (or more correctly in) the Serpentine River.

\section{THE BARRAGUP FISH WEIR}

Dortch's (1997: 15-16) review of the nature and mechanics of fishing in south-west Western Australia, summarises the techniques into four main categories:

1. Spearing of fish by individuals - spearing from the banks and shallows of rivers and estuaries, sometimes at night using torchlight.

2. Tidal weirs - composite structures of stakes, brush and/or stone, situated on estuarine and tidal river shores.

3. Fish drives - groups of people driving fish into shallows or into brush barricades.

4. Fish traps - wooden structures situated on (tidal) rivers or freshwater streams.

The ethnohistorical record suggests that the latter form of fish trap (or more properly, a fish weir) was quite common along the Swan Coastal Plain (Armstrong 1836; Bunbury 1930: 69; Shenton and Wells 1837; Grey 1841: 275, 296; Perth Gazette 25/3/1843; Baudin 1977). The common name appears to have been mungah (Hammond 1933: 46), or its alternates of manga (Bunbury 1930: 69) or mungo (Paterson 1896: 289).

During the drier months the Peel, Harvey and Leschenault Inlets, as well as the lower reaches of some of the other river systems, become increasingly saline and are used by marine fish as a nursery 
environment after spawning in the oceans (Lenanton 1984). The first flood of fresh waters from the winter rains then flushes these species, in particular the sea mullet (Mugil cephalus) and Australian salmon (Arripis truttaceus), known to Nyungar people as kalda and ngarri, respectively, back down into the lower reaches of the rivers (Moore 1884: 38, 66). The weirs were constructed across the channels to focus the flow of water and consequently the passage of the fish through one or more narrow channels. Although some weirs appear to have been quite simple temporary structures of bushes pinned into place with stakes (e.g. Buller-Murphy n.d.), the various accounts of Barragup suggest that this was an extensive and well constructed mechanism, made to last for substantial periods of time to save the labor of an annual total reconstruction.

The Barragup weir was constructed in the lower reaches of the Serpentine River, $4.5 \mathrm{~km}$ from the Indian Ocean, but only $2.5 \mathrm{~km}$ from the Peel Inlet estuary into which it discharges (Figure 1). Bates (1985: 251) reports the name of the site as Berreek, which when joined with the usual South-West affix '-up' indicating 'place of', forms a close alternate (i.e. 'Berreek-up'). The most detailed physical descriptions of the weir are from Jesse Hammond (1933: 46), who appears to have seen the structure as early as the 1860 s.

To make this trap they chose the narrow neck of the river, at Barragup on the Serpentine, where the water was up to about four feet in depth. A wicker fence was built across the stream, completely closing it from bank to bank, except in the centre, where a small opening was left. Through this opening a race was constructed by driving two rows of parallel stakes in the riverbed. The bottom of the race was filled with bushes, until there was only about eight inches of clear water above the bushes for the fish to swim through. On either side of this race was built a platform, about two feet six inches below the top of the water. On these platforms the natives stood to catch the fish as they swam through the race. The fish were caught by hand as they passed over the bushes and were thrown to natives who were waiting on the bank to receive them.

Hammond also drew a diagram of the fish weir at Barragup (Figure 2), the top part of which was reproduced in his book Winjan's People (Hammond 1933: 47). Figure 3 is a c. 1900 photograph of a fish weir which appears to be of a similar type to Barragup. Although the original caption states the weir was located on the Murray River, it is conceivable that it is Barragup which was situated on the nearby Serpentine River. Bates (1985: 251) and Paterson (1896: 289) both provide very similar descriptions of the structure. Observing fish weirs further south, Bussell (1833: 197) commented that the spears of the grass tree (Xanthorroea sp.) were also used 'as stakes for fish snares'. Later oral histories from the Mandurah area collected by Stranger (1972) suggested that the poles were worked into the mud by moving them backward and forwards. His diagram of Barragup, based on these oral testimonies, shows that the stakes were placed on an angle leaning upstream, a point not mention by other writers.

Bates (1985: 251) adds that the people operating the trap sat on either side of the race facing each other, 'their hands half opened and spread downwards, and as the fish came through the opening the natives (sic) caught them and nicked them on the back of the neck with their teeth before throwing them on land'. However, there is also evidence to suggest that nets or baskets could also be placed under the exits to the race (Hackett 1886: 343; Paterson 1896: 289; Stranger 1972; Bates 1985: 251).

Weirs were resorted to in the swampy channels, these being formed of brushwood intertwined on stakes, with here and there a pocket, at the bottom of which a kind of basket would be constructed. (Austin in Roth 1902: 47)

Bates (1985: 251) notes that in the Murray district the weirs 'were supplemented by a species of interwoven wire grass, with the tenacity and

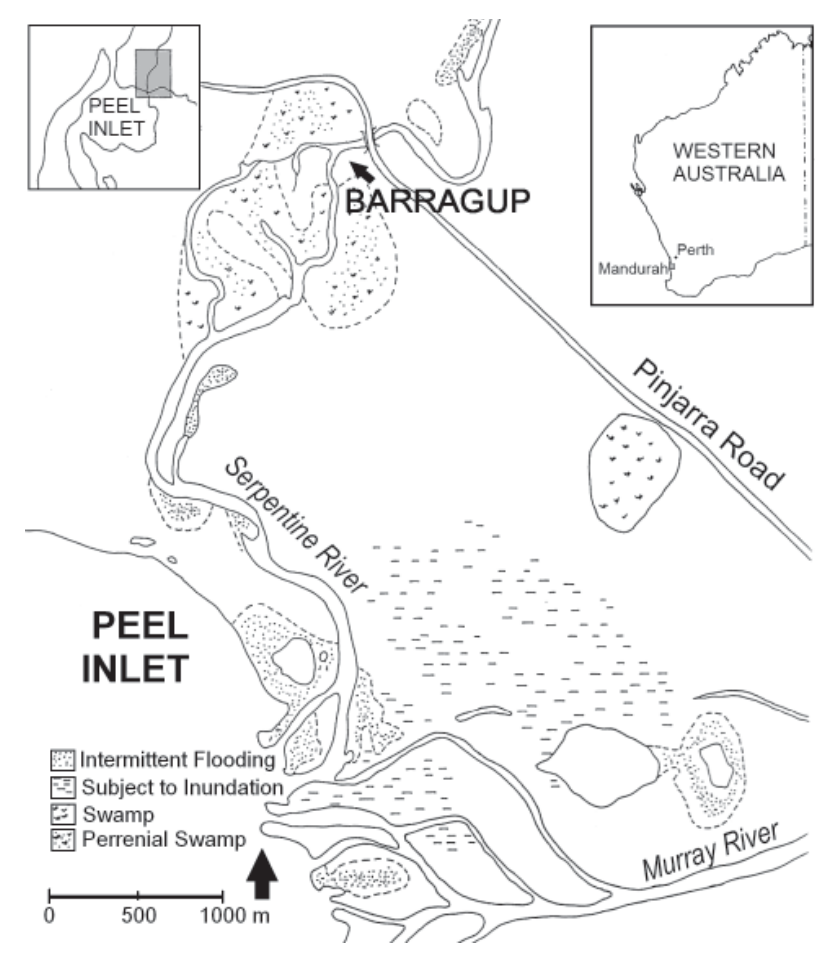

FIGURE $1 \quad$ Location map - Barragup. 
strength of the strongest fibre, which was drawn netfashion through shallow or deep water'. Although there is no evidence that South-West Aboriginal groups manufactured nets, this woven grass may be what Bates describes elsewhere as ngoondjuck (Bates n.d. VIII, 1, 45).

There is no information on the antiquity of the Barragup fish weir; although the ethnohistorical record suggests that operation of weirs of this type was a well established and significant activity. In September 1831 the Commandant of the Swan River Colony, Frederick Irwin, reported that 40 Aboriginal men, decorated with red ochre and without women or children present, had mounted an attack on the settlement at the Murray River. He suggested that this attempt to dislodge the white colonists was due to their coming too close 'to weirs in that part of the Murray for the purpose of catching fish' (Irwin 1831: 98). Hammond (1933) states that he last saw a weir of the Barragup type used in the 1870s, implying he observed them in the 1860s or earlier when he lived in the Mandurah area as a young boy (Hammond 1936: 2). Paterson (1896) also speaks of the gathering in the past tense. It is difficult to assess what proportion of Bates' information comes from the memory of her informants, which could date it to the 1840 s or 1850 s, or from personal observations, which would come from the first decade of the 20th century.

Here is a short origin story recorded by John Forrest (later Lord Forrest) entitled 'The reason why Barragup on the Serpentine was named'.

A long time ago Boolyun lived. He was half man and half kangaroo. He had a long tail, and made a manga to catch fish - and when the water was too high, he struck the water with his tail and caught fish easily. (Forrest n.d.; cf. Richards 1978: 20)

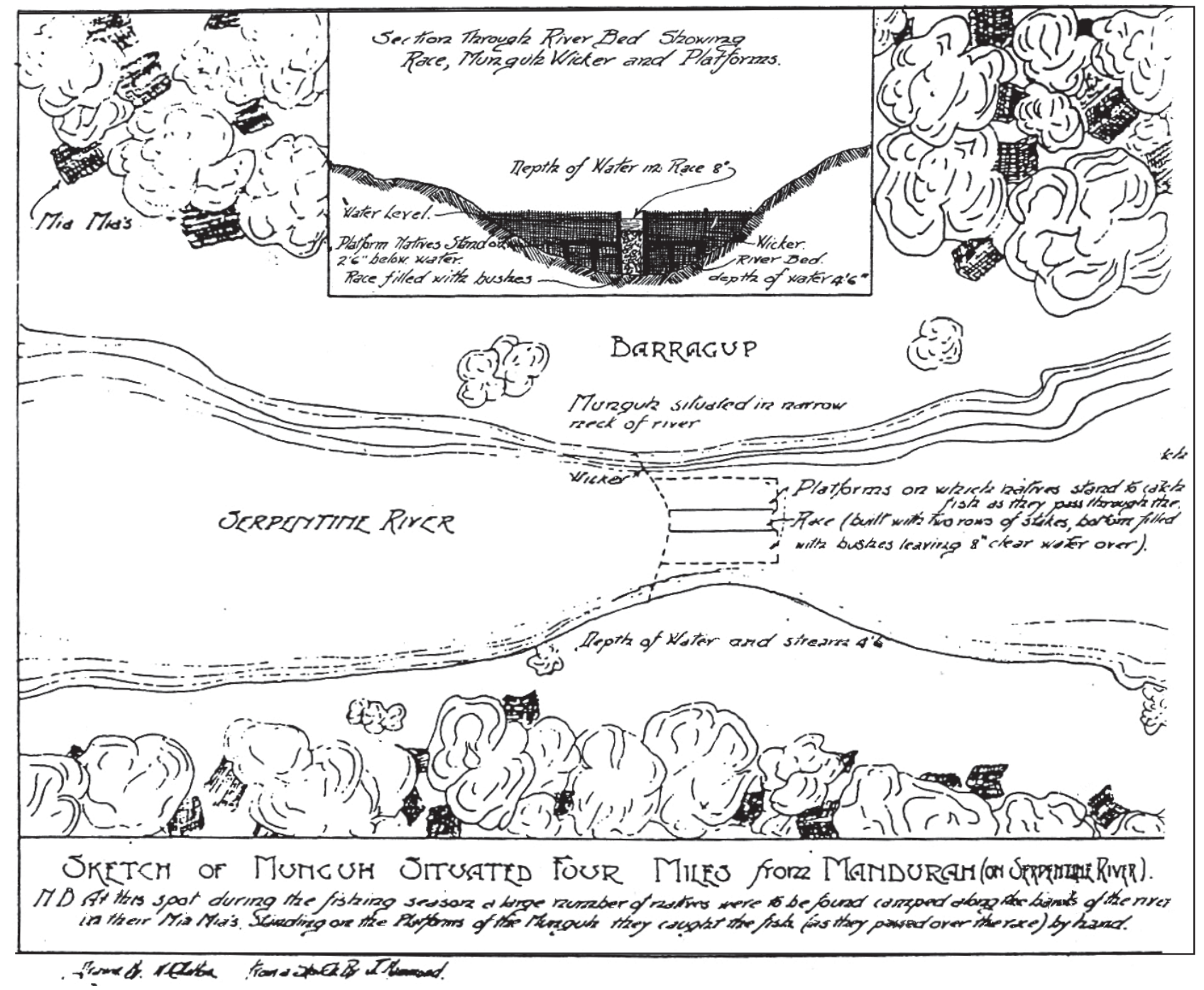

FIGURE 2 Sketch of a Munguh situated four miles from Mandurah (on Serpentine River). No. WU/P417. Courtesy Berndt Museum of Anthropology, University of Western Australia. 
TABLE 1

Groups attending the Barragup gathering.

\begin{tabular}{ll}
\hline Bates (1985: 251) & $\begin{array}{l}\text { 'Perth, Gingin and other } \\
\text { districts visit Mandurah } \\
\text { during fishing season.' }\end{array}$ \\
\hline Hammond (1933: 46) & $\begin{array}{l}\text { 'hundreds of natives } \\
\text { from East and North } \\
\text { districts, as well as from } \\
\text { the South-West.' }\end{array}$ \\
\hline Paterson (1896: 289) & $\begin{array}{l}\text { 'All districts, inland and } \\
\text { coastal.' }\end{array}$ \\
\hline Stranger (1972) & 'Some of the natives \\
& came considerable \\
& distances ... ('hundreds \\
& of miles' could be an \\
& exaggeration though).' \\
\hline Bates (nd XI, 1: 110) & 'Murray and Pinjarra \\
& men would go as far \\
& as Dandaragan for \\
& ceremony.' Bates (nd III, \\
& 16, 11) \\
\hline 'Mandurah tribes \\
met with and \\
intermarried with \\
Perth and Fremantle, \\
Bunbury, Busselton and \\
Blackwood.'
\end{tabular}

'Daaja-wa gabba la?' (fish all gone to the sea?), and the desired invitation would soon come. (Bates n.d. VIII, 1, 46)

There are no specific accounts of groups moving to Barragup, although Hammond (1933: 19) records two major tracks (bidi) from Perth, one along the chain of lakes that lies parallel to the coast, the other inland, along the line of the Darling Ranges. Bunbury (1930) traveled from Pinjarra southward to the Vasse along paths that edged the estuaries and swamps, which were probably major routes of movement. There is a single historical account from February of 1833 (Perth Gazette 16/2/1833), in which 90-100 Aboriginal people visited Perth for a short period, and then passed along the Canning River, allegedly en route to an 'annual battle' with another tribe for control of the best fishing and hunting grounds. This is earlier than might be supposed for the operation of the mungah and since they warned Europeans not to follow them, there is no further information. However, the possibility remains. Some form of organization must have been behind the process of moving to Barragup, as Bates (nd V, lc) noted that 'contingents generally arrived within a few days of each other'. It is possible that the messengers also acted as guides, to co-ordinate movements.
TABLE 2

Estimates of the number of participants at Barragup gatherings.

\begin{tabular}{ll}
\hline Bates (nd. I: 42) & $\begin{array}{l}\text { 'Great numbers from } \\
\text { outlying districts' }\end{array}$ \\
\hline Bates (White 1985: 325) & 'great assemblages' \\
\hline Paterson (1896: 288) & $\begin{array}{l}\text { 'natives from all } \\
\text { districts' }\end{array}$ \\
\hline Hammond (1933: 26) & 'hundreds' \\
\hline Ilbery (1927) & 'invited friends from \\
& other groups' \\
\hline Bates (nd XI, 1: 110) & 'Mandurah tribes \\
& met with and \\
& intermarried with \\
& Perth and Fremantle, \\
& Bunbury, Busselton and \\
& Blackwood.' \\
\hline
\end{tabular}

As one of the major ceremonial events on the Swan Coastal Plain, Barragup seems to have attracted hundreds of people, although there are no specific figures given (see Table 2). Hammond (1933, 1938) considered it as important as the annual gathering at Bailup, further to the south-east, which included over 300 people at its ceremonies. One clue is from Hammond's description of the organization of the campsite near the mungah. As was usual for meetings between different Aboriginal groups, they camped apart, with their huts located in the direction of their homeland, which is also noted specifically for Barragup by Bates (n.d. V, lc). Hammond described the campsite as having consisted of approximately 30-50 'mia-mias' (huts), with an average of six in each (suggesting between 180 and 300 people), covering over half an acre of ground.

Undoubtedly, the realities of campsite organization would have been very complex, with separate camps for young men and women, satellite camps for strangers and people in seclusion, and camps placed at a distance for ceremonial purposes. Hammond's illustration of Barragup (Figure 3) shows huts built on either side of the river, around the mungah itself, but should probably be dismissed as a stylized representation rather than an accurate depiction. Although the main concern of this paper is not the archaeology of the site, Hallam (pers. comm.) advised that her survey around the area of Barragup in the 1970s had revealed little or no remaining stone material other than a few quartz chips and scrapers. If, as Hammond's drawing suggests, the huts were built close to the banks, seasonal flooding might have covered or destroyed campsite remains. When the author visited the site in 1987 no artifacts were visible, while the higher ground behind the mungah site was in the process of being been cleared and redeveloped for housing. 


\section{THE NGARRI MAIA (SALMON SONG)}

The physical construction or reconstruction of the Barragup fish weir was paralleled by spiritual preparations. One of the most important aspects of the ethnohistorical record of Barragup is that we know something of the specific ceremonial and social activities that went on there; a rarity for the South-West of Western Australia and especially the Swan Coastal Plain. The most detailed material comes from Daisy Bates' published and unpublished manuscripts, which includes two versions of the ceremonies associated with the operation of mungah. The group controlling the Barragup weir performed the Ngarri Maia (salmon song), which was very similar to the Kalda Kening (sea mullet song) used for weirs in the Vasse (Busselton) area (Bates 1985: 324-326; Bates n.d. V, lc). Both performances asked the Demma Goomber (Great Grandparent or totem ancestor) to ignore cries from the fish, and to help the people with their fishing instead. Bates recorded the Ngarri Maia as initially sung by the older members of the salmon totem when the fish first came into the estuaries (Bates n.d. V, lc), although her actual description of the song (below) suggests that it was performed immediately before the fishing commenced, as was the Kalda Kening.

When all the camps are pitched ... the oldest member of the ngarri borungur begins the 'Ngarri Maia', the words of which are as follows;

\section{Ngarri bi ngarri \\ neana mooga \\ koort beet, beet-al-wa \\ kalbarn yaa wadarn}

As the old man chants these words he makes many motions with his hands in imitation of the movements of the salmon. He shows the fish rushing through the incoming waters, gliding onwards to its kalleep (fire or home). Then the various motions of spearing it, hitting it with a kaili (boomerang), or driving it into the shallow waters of the estuary are gone through thoroughly by the singer, who now and then utters a kind of a kissing sound, or a 'brrrrr' to represent the rushing of the fish through the narrow waters of the rivers on their way upstream.

Now he is seated by the small opening left in the weir, and makes the motion of catching and killing the fish as it forces its way through the narrow gap, pretending to make a great heap as the song goes on. He is joined in the song and movements by other elders present, until presently every initiated borungur is singing and imitating the actions of the fish.
All around the singer the visitors are seated listening to the song ... but although they know the song by constant repetition, none of the visitors take any part in it, nor will they take part in the actual fishing, or rather in the catching of the fish at the small weir openings the next day, for only the kaleepgur can catch ngarri. (Bates n.d. $\mathrm{V}, \mathrm{lc}$ )

The Kalda Kening is similar and includes totem kin and elders performing the actions of the fish and the fishermen (Bates 1985: 324). The Kalda Kening is said to have lasted only one afternoon and evening (Bates n.d. V, 1f, 41), so this may be have been the case for the Ngarri Maia as well. Older members of the totem group would continue to 'sing' the fish at least once a day, to ensure a good supply of food for the gathering.

\section{FOOD COLLECTION AND DISTRIBUTION}

As suggested by Bates' description of the Ngarri Maia, only the members of the salmon totem, the kaleepgur (people of that country, cf. Grey 1840), were allowed to operate the mungah. There was a belief that the fish ' $k$ new' the ngarri borungur (salmon totem kin) and would not be disturbed by them. However, they would become frightened and leave the area should a stranger attempt to collect the fish.

Because they eat the noomar and joobuck (a type of fungus and root), the fish will not come where they smell noomar. (Bates n.d. VIII, 1, 55)

Stranger (1972) collected a story from the turn of the century that Europeans or people with the smell of cigarette or fire smoke on them were not allowed near the mungah, as this was thought to repel the fish.

The weir was watched night and day by both men and women, with a system of shifts that were relieved after a certain period of time (Paterson 1896: 289; Hammond 1933: 46). There was a belief that if any fish escaped through the mungah, they would tell all the other fish, who would then avoid the trap (Hammond 1933: 46; Stranger 1972). As a result of this, thousands of fish were caught at the weir, and whatever could not be eaten would be thrown back into the river after two or three days. Stranger's (1972) informants remarked that the piles of dead fish attracted thousands of crows, so that all that could be seen when the mungah was operating were 'Aborigines and crows'. While the visitors to Barragup were given as many fish as they could eat, the ngarri borungur would not eat any fish for a few days after the singing of the Ngarri Maia.

Hammond (1936: 17) describes how the surplus 
of fish from Barragup also became important to the early European settlers around the Murray region, both as a food source and as fertilizer for their crops. A cartload of fish could be bought from the Aborigines at the mungah;

for which they paid half a pound of tobacco (then only 5s. a pound), a few pounds of flour, and some tea and sugar - less than 10s. in all. When asked to, the natives would open up the fish and take out the entrails for the whites, for they placed a great deal of value on the fish fat, which they used for many purposes. (Hammond 1936: 17)

While fish were obviously the most vital resource during the time of the gathering, Bates' statement that the visitors lived exclusively on fish for two or three months (Bates 1985: 251) is invalidated by her unpublished notes. According to these manuscripts (Bates n.d. V, lc), members of the visiting groups went out daily to hunt. Paterson's (1896: 295) notes indicate this may well have included fishing by other means in the nearby estuary and swamps. Indeed, one of the reasons for the location of the Barragup weir appears to have been that the swamps nearby provided an additional food supply (Paterson 1896: 295). All bush spoils were brought back to the host group "who would divide the food in the proper manner' (Bates n.d. V, lc). Apart from providing an alternative to the fish diet, hunting gave the men (and women) a chance to show off their skills to other groups. However, it is important that the host group retained control over the use of resources in their territory and decided upon the correct redistribution.

\section{CEREMONIAL AND SOCIAL ACTIVITIES}

When the tribes have collected, the oldest man addresses them on the first evening. He begins with 'Yungar Aw' (ye people), then mentions the name of each 'bidere' or old man of each tribe and asks if they hear him. Each answers 'yes, we hear'. The speaker then says they meet to hold corroboree, not fight, and that it would be better to have no quarreling, and to part as friends. (Bates n.d. XIII, 2, 69)

Barragup was clearly one of the major annual ceremonial events along the Swan Coastal Plain. Bates (n.d. XI, 1, 42) describes various ceremonies and dances (kening) as taking place at Barragup, including the wanna-wa (or jalgoo), manja boming (fire exchange) and bibbul kening. Descriptions and explanations of these can be found in her published and published notes (Bates 1985: 326-334; Bates n.d. XI, 1, 42) and need not be repeated here. Paterson
(1896: 290) also describes the 'Wild Man Corroboree' taking place at Barragup, which he says took two weeks of preparation and was kept hidden from the old men and women. It is possible that this is the same ceremony as Bates' wanna-wa.

Apart from ritual performances, social life dominated the Barragup gathering. Old friends and enemies met, debts were settled and occasionally fights broke out between individuals and small groups. Generally an effort was made to conduct the gathering in an amicable atmosphere, since the occasion was supposed to be lighthearted and enjoyed by its participants.

Dancing, singing, dajjeluck giving and babbin making ceremonies are carried on by all the assembled tribes while the visit lasts, and many new friendships, and some new enemies may be formed amongst the young men. (Bates n.d. V, lc)

The older members of families arranged dajjeluk or infant betrothals, while girls who were of suitable age were passed into the care of their future husbands' families. Arrangements were also made for the exchange of initiates, and in some cases people would take the opportunity to go back with different groups, staying for a month or two.

When two individuals of either sex formed a special friendship, they might choose to go through the babbin friendship ceremony, which formally pledged a lifelong bond (Paterson 1896: 289; Bates 1985: 153). Along with this vow went special responsibilities, so that the babbin would be obliged to hospitality if one visited the other's area. This included sharing food and hunting together, guarding each other, and exchanging goods with each other until death (Bates 1938). Babbin who were especially close might also share names and totems, as well as have special ceremonial roles towards each other, such as piercing a boy's nose at initiation.

Aside from those recorded by European observers, a range of other sacred and public ceremonies and rituals must have been held at Barragup. Unlike most gatherings along the Swan Coastal Plain it was regular with a large and diverse representation from other groups and a range of ritual expertise and potential participants. Hammond (1933) speaks of the older men meeting at large gatherings such as Barragup to discuss matters of law, a type of council that made important decisions about the distribution of people, punishments for offences, approval for betrothals and initiations, as well as matters of ritual. Given the structure of the mungah, only a dozen or so individuals of the Murray community (the largest group of participants) were occupied with food collection at any one time. This allowed the majority to take part in the ceremonies and social 
activities. Furthermore, the abundant supply of fish ensured that there was no apparent haste during the gathering, so that many ceremonies could be completed at the one event.

Sporting and competitive athletic events were a feature of Barragup, with men and women showing off their prowess. Bates (n.d. XI, 4a) devotes a whole section to the types of games and amusements seen at South-West gatherings, including point to point swimming races in the estuaries and rivers, running and climbing contests (using the kodja axe), and tests of skill in spear and boomerang throwing. A notable game played during the mungah gathering was deedagurt ('nut striking').

Bareegup (sic) near Mandurah, was a famous hockey ground, and during the fishing season (jilba), was the time when natives assembled to play the game. (Bates n.d. XI, 4a, 5)

The game was played with a red gum nut (meetcha) and a crooked stick (bandeegurt). An area of ground was cleared and two rings marked at either end of the field. The object of the game was the same as in hockey, with sides of 20 men and women trying to hit the nut into the 'goals'. The game was apparently extremely rough, and usually ended with broken bones and a fight. It started in the early morning and was played all day, except for when ceremonies were being performed (Bates XI, 4a, 5; Buller-Murphy n.d., 14a).

Finally, Barragup was known as a significant mandjar or trade gathering (Bates 1985: 332; cf. Brady 1845; Grey 1840: 89). Moore (1884: 49) described a mandjar as:

A sort of fair which takes place between the Aborigines, where inhabitants of different districts meet to barter with each other the products of their respective countries.

The name of Mandurah, presumably based on an original name something like 'mandjar-up', or place of the mandjar, preserves the significance of the MurraySerpentine confluence for these major gatherings.

The exchange of material and non-material items at mandjar occurred in a number of contexts, ranging from straight bartering, to the giving of gifts as payment for services or as part of ceremonial performances. Although writing about the Vasse area, Bates (1985: 326) describes how the visiting groups at a mungah gathering were required to pay the host group for the food they consumed.

Sometimes, when the visitors have all arrived for the fishing, an old totem man will sing the following: ngaija been yaan, naara beenyaan,

woordoomanoo yaan,

I come, dancing come, brothers come,

naara been yaan,

dancing come,

yandaara gwabeen marra yanga gooling,

beerart gwabeen.

white ashes and pipeclay good, food going to give, fur ornaments good.

In the original dissertation (Gibbs 1987) there is more detail on trade items and trajectories along the Swan Coastal Plain. Grey (1840: 89) lists the range of trades that would take place between the Murray and Perth peoples at a mandjar (Table 3).

\section{DURATION OFTHE BARRAGUP GATHERING}

Hammond (1933: 26) estimated that Barragup lasted for a month, while Bates (1985: 251) suggested that two to three months as quite normal, making it a relatively long event. Various factors determined its ending each year, with Bates reporting:

When the visitors have been satiated with fish, they prepare for their return journey to their own kalleep. In this way they may be accompanied by some old or new kobongur, who will sojourn with them for weeks or months, according to the popularity of the young kobong in camp. (Bates n.d. $V$, lc)

Hammond (1933: 26) writes that participants left in accordance with the weather conditions, or whether the mungah was washed away by floodwaters. People would obviously wish to return to their homes before the worst of the winter rains started to fall, as well as to be in time to exploit that season's special resources within their own country. If the rising waters did not wash away the weir, the Murray group would need to demolish at least part of the mungah anyway, to allow the next year's fish to pass upstream.

\section{THE END OF BARRAGUP}

Despite Hammond's statement that mungah were last used in the 1870s, in the late 1890s New South Wales fisheries inspector Mr. Lindsay Thompson visited and reported on the Barragup weir. Since it was not yet understood that the salmon did not actually spawn during their migration upstream, Thompson felt that it was obstructing the movement of the fish and reported that the mungah was 'a 
Table 3

Goods traded between Murray and Perth groups (after Grey 1840: 89; translations from Bindon and Chadwick 1992).

MURRAY MEN

\begin{tabular}{|c|c|c|c|}
\hline Nool-burn & $\begin{array}{l}\text { Opossum hair girdle } \\
\text { (nulbarn/nulboo) }\end{array}$ & kat-jew & $\begin{array}{l}\text { 'Possibly Grey's 'kat-djo' } \\
\text { - a hammer, a hatchet'. }\end{array}$ \\
\hline Boor-doon & War spear & Koon-yee & $\begin{array}{l}\text { 'A kind of wool-burn'. } \\
\text { Possibly nul-burn or hair belt? }\end{array}$ \\
\hline$T a b-b a$ & Hafted stone knife & Boka & Kangaroo skin cloak \\
\hline Wal-ga & Club (for killing game) & Woon-doo & Shield (wunda)? \\
\hline Tdoor-de-re & $\begin{array}{l}\text { Dark red ochre (thooarree)? } \\
\text { Dog tails (dooda/doorda)? }\end{array}$ & Bu-ye & $\begin{array}{l}\text { Headpiece of human hair (wundu)? } \\
\text { stone }\end{array}$ \\
\hline Ko-kil-yung & $\begin{array}{l}\text { Ornamental tuft of } \\
\text { feathers }\end{array}$ & & \\
\hline Dew-ar & Throwing stick? & & \\
\hline Wil-gey & ochre & & \\
\hline Ngow-er & Cockatoo feather ornament & & \\
\hline Nig-ga & $\begin{array}{l}\text { Human hair girdle or } \\
\text { waistband (niggara) }\end{array}$ & & \\
\hline
\end{tabular}

PERTH MEN

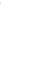

terrible engine of destruction' (Stranger 1972). He recommended that it be partially destroyed in the interests of fish conservation (Stranger 1972). This did not happen, as Stranger's informants recalled that at the start of the 20th century and possibly as late as the 1930s, the mungah was still intact, except for a six-foot hole in the middle through which fishing boats could pass. To overcome this, Aboriginal people still using the weir began placing nets of 'tangle grass', shaped something like a prawn net, in the opening (Stranger 1972). Richards (1978: 465) describes how the Murray and Serpentine Rivers and other watercourses were 'snagged' during the depression years as a public work (see also Stranger 1972), and the last remains of the Barragup mungah removed.

Ethnographic surveys have indicated that the Aboriginal communities of Pinjarra and Mandurah are still aware of the significance of the site (O'Conner et al. 1984) and in recent years have included the Barragup site in cultural tours of the area, as well as a recreation of a mungah developed as an art installation in a Murray region community centre. In addition to the archaeological surveys described above, a brief underwater survey by the staff of the Western Australian Maritime Museum in about 1989 located a single axe-sharpened stake in the area of the weir, although its association with the mungah cannot be demonstrated. 
to the operation of the social, economic and ceremonial network for the Aboriginal communities of the Swan Coastal Plain. It was designed to take advantage of natural conditions, allowing maximum yield of fish with reduced labor cost (after initial construction), and thus freeing the majority of participants for the various non-subsistence activities of the gathering. The resource itself was tightly controlled by the host community through spiritual/totemic restrictions and sanctions, which also returned them various advantages through the system. Collectively, these processes reflect on the trajectory of changes that were taking place and are mirrored in the archaeological record. It was clearly a part of a system that required these features.

\section{SYLVIA HALLAM - AN ACKNOWLEDGEMENT}

As this is a festschrift it is appropriate to comment briefly on the impact of Sylvia Hallam's work and teaching on my own career and research interests. After completing my Honours thesis my attention was captured by the potential of the documentary record in other types of Australasian archaeological research, leading me towards historical and maritime archaeology. I have only recently started to return to some of my earlier ethnohistorical interests, partially seduced by the elegant writings of Harry Maude, Greg Dening and the Pacific ethnohistorians. This has included publishing on Aboriginal involvement in the colonial whaling industry (Gibbs 2002), relations between coastal Aboriginal groups and shipwreck survivors (Gibbs 2003), and contact period changes in Aboriginal social and ceremonial patterns (Gibbs and Veth 2002). However, as a consequence of trying to unearth my own historical research materials, I have renewed respect for how well Sylvia was organised when it came to her data. After more than a decade of full-time lecturing in archaeology, I have also come to appreciate Sylvia's skill as a teacher: her breadth of interests, her enthusiasm for the discipline, as well as her ability to make students feel that they had said something worthwhile and interesting, even if she had obviously heard it a dozen times before. Hopefully there is an echo of Sylvia in my own teaching. I am sure that, along many of the others who have contributed to this volume, I will continue to be grateful for her tutelage for years to come.

\section{REFERENCES}

Armstrong, F. (1836). Manners and habits of the Aborigines of Western Australia, from information collected by Mr. F. Armstrong, Interpreter. Perth Gazette 29/10/1836, 5/11/1836, 12/11/1836.

Bates, D.M. (n.d.). Unpublished manuscripts and notes. Battye Library Accession 1212A (Roman numerals indicate sections and folios as indicated on the manuscripts).

Bates, D.M. (1938). The passing of the Aborigines. John
Murray: London.

Bates, D.M. (1985). The native tribes of Western Australia. White, I. (ed.), National Library of Australia: Canberra.

Baudin, N. (1977). The journal of Post Captain Nicolas Baudin Commander-in-Chief of the corvettes Geographe and Naturaliste. Translated by C. Cornell. Library Board of South Australia: Adelaide.

Bindon, P. and Chadwick, R. (1992). A Nyoongar wordlist from the south-west of Western Australia. Western Australian Museum: Perth.

Brady, J. (1845). A descriptive vocabulary of the native language of Western Australia. Press of the S.C. De Propaganda Fide: Rome.

Buller-Murphy, D. (n.d.). Meekadarriby - the legends, art, customs and language of the Aborigines of the S.W. and N.W. of Western Australia. Battye Library (PR 1648a/7).

Bunbury, H.W. (1930). Early days in Western Australia. Morrell, W.P. (ed.). Oxford University Press: London.

Bussell, J.C. (1833). Report of an excursion to the northwest from Augusta. (pp.178-185). In: Cross, J. (ed.), Journal of several excursions in Western Australia. J. Cross: London.

Churchward, H. and McArthur W.M. (1980). Landforms and soils of the Darling System, Western Australia ( $p p$. 25-33). In: Atlas of natural resources, Darling System, Western Australia: explanatory text. Department of Conservation and Environment, Western Australia. University of Western Australia Press: Nedlands.

Dortch, C. (1997). New perceptions of the chronology and development of Aboriginal estuarine fishing in southwestern Australia. World Archaeology 29: 15-35.

Ferguson, W. (1985). A Mid-Holocene Depopulation of the Australian Southwest. PhD thesis, Australian National University: Canberra.

Forrest, J. (n.d.). The reason why Barragup on the Serpentine was named. Battye Library (PR 390a).

Gibbs, M. (1987). Aboriginal gatherings in the west coastal region of southwest Western Australia: an ethnohistorical study. BSc Honours (Archaeology) thesis, Centre for Prehistory, University of Western Australia: Nedlands.

Gibbs, M. (2002). The enigma of William Jackman 'The Australian captive' - fictional character or shipwreck survivor? Great Circle - Journal of the Australian Society for Maritime History 24(2): 3-21.

Gibbs, M. (2003). Nebinyan's song - the Aboriginal whalers of southwest Western Australia. Aboriginal History 27: 11-20.

Gibbs, M. and Veth, P. (2002). Ritual engines and territorial ascendancy (pp. 11-20). In: Ulm, S., Wescott, C., Reid, J., Ross, A., Lilley, I., Prangnell, J. and Kirkwood, L. (eds), Borders, barriers and boundaries. Tempus 7. Anthropology Museum, University of Queensland: St Lucia.

Green, N. (1984). Broken spears. Focus Education Services: Perth.

Grey, G. (1840). A vocabulary of the dialects of south western Australia. T. and W. Boone: London.

Grey, G. (1841). Journals of two expeditions of discovery in north-west and western Australia; during the years 1837, 1838 and 1839. 2 volumes. T. and W. Boone: London.

Hackett, D.E. (1886). York district: Ballardong or Ballerdocking Tribe (pp. 342-45). In: Curr, E. (ed.), The Australian race. Government Printers: Melbourne.

Hallam, S.J. (1975). Fire and hearth: a study of Aboriginal usage and European usurpation in south-western Australia. Australian Institute of Aboriginal Studies: Canberra. 
Hallam, S.J. (1977). Population and resource usage on the Western Littoral. Memoirs of the Victorian Archaeological Survey 2: 16-36.

Hallam, S.J. (1983). A view from the other side; or 'I met a man who wasn't there'. (pp. 95-121). In: Smith M. (ed.), Archaeology at ANZAAS 1983, Western Australian Museum: Perth.

Hallam, S.J. (1985). The history of Aboriginal Firing (pp. 7-20). In: Ford, J.R. (ed.), Fire ecology and management in West Australian ecosystems. Western Australian Institute of Technology: Bentley.

Hallam, S.J. (1986). Yams, alluvium and villages on the West Coastal Plain (pp. 116-132). In: Ward, G.K. (ed.), Archaeology at ANZAAS Canberra. Canberra Archaeological Society: Canberra.

Hammond, J.E. (1933). Winjan's people; the story of the southwest Australian Aboriginals. Imperial Printing: Perth.

Hammond, J.E. (1936). Western pioneers; a battle well fought. Imperial Printing: Perth.

Hammond, J.E. (1938). Native laws, rites, customs, ceremonies and religious beliefs; when in their primitive state. Battye Library (PR 385).

Ilbery, E. (1927). The passing of the Bibbulmun. Early Days. Journal of the Proceedings of the Royal Western Australian Historical Society 1: 24-30.

Irwin, F. (1831). Correspondence from F. Irwin to Lord Somerset, 8 January 1831. Swan River Papers, Vol. 7: 98-101. Battye Library: Perth.

Lenanton, R.C.J. (1984). Life history strategies of fish in some Temperate Australian Estuaries (pp. 119-137). In: Hodgkin, E.P. (ed.), Estuarine environments of the Southern Hemisphere. Dept of Conservation and Environment, Western Australia, Bulletin No. 161.

Lourandos, H. (1980). Change or stability?: hydraulics, hunter-gatherers and population in temperate Australia. World Archaeology 11: 245-264.

Lourandos, H. (1983). Intensification, a late PleistoceneHolocene sequence from south-western Victoria. Archaeology in Oceania 18: 81-94.

McBryde, I. (1979). Ethnohistory in an Australian context: independent discipline or convenient data quarry? Aboriginal History 3: 128-151.

McBryde, I. (1984). Exchange in South Eastern Australia: an ethnohistorical perspective. Aboriginal History 8: 132-153.

McBryde, I. (1986). Artefacts, language and social interaction: a case study from south-eastern Australia (pp. 77-93). In: Bailey, G. and Callow, P. (eds), Stone age prehistory: studies in memory of Charles McBurney. Cambridge University Press: Cambridge.

Meagher, S.J. (1974). The food resources of the Aborigines of the southwest of Western Australia. Records of the Western Australian Museum 3: 14-65.
Meagher, S. and Ride, W. (1980). Use of natural resources by the Aborigines of south-western Australia (pp. 6680). In: Berndt, R. and C. (eds), Aborigines of the west: their past and present. University of Western Australia Press: Nedlands.

Moore, G.F. (1835). Excursion to the northward. Perth Gazette 26/4/1835, Perth Gazette 2 May 1835.

Moore, G.F. (1836). A new river discovered to the northward by the Hon. G.F Moore on a recent expedition northward. Perth Gazette 13 May 1836, 21 May 1836, 29 May 1836.

Moore, G.F. (1884). A descriptive vocabulary of the language in common use amongst the Aborigines of Western Australia. Addendum to: Moore, G.F. Diary of ten years eventful life of an early settler in Western Australia. M.Walbrook: London.

O'Conner, R, Bodney, C. and Little, L. (1984). Preliminary report on survey of Aboriginal areas of significance, Perth Metro and Murray River regions. Unpublished report for the Aboriginal Sites Department of Western Australia: Perth.

Paterson, C.A. (1896). Notes about the tribes inhabiting the coastal districts from Geraldton to Albany, and those of territories nearest adjoining them. (pp. 288-291). In: Helms, R. (ed.), Anthropology of the Elder scientific expedition. Transactions of the Royal Society of South Australia.

Pearce, R. (1982). Archaeological sites in the jarrah forest, southwest Western Australia. Australian Archaeology 14: 18-24.

Perth Gazette - Perth Gazette and W.A. Journal Newspaper. (Battye Library, Western Australia).

Richards, R. (1978). The Murray district of Western Australia. Shire of Murray.

Roth, W.E. (1902). Notes of savage life in the early days of West Australian settlement; based on reminiscences from F. Robert Austin. Proceedings of the Royal Society of Queensland 17: 45-69

Shenton, W. and Wells, R. (1837). Excursion to the Collie and Brunswick Rivers in the County of Wellington, Western Australia, by Messrs Shenton and Wells. Perth Gazette 23 December 1837.

Stranger, R. (1972). The Barragup Mungah. Letter to Western Australian Museum 11 March 1972.

Tindale, N.B. (1974). The Aboriginal tribes of Australia. Australian National University Press: Canberra.

Tindale, N.B. (1976). Some ecological bases for Australian tribal boundaries, (pp. 12-29). In: Peterson N. (ed.), Tribes and boundaries in Australia. Australian Institute of Aboriginal Studies: Canberra.

MANUSCRIPT RECEIVED JULY 2005; ACCEPTED AUGUST 2008. 